\title{
ANASIR SUFISTIK DI DALAM WUJUD SI CEPOT GIRI HARJA 3
}

\author{
Lingga Agung Partawijaya \\ Universitas Telkom, Program Studi Desain Komunikasi Visual \\ Jl. Telekomunikasi No. 1, Dayeuh Kolot, Jawa Barat \\ linggaagungpartawijaya@gmail.com
}

\begin{abstract}
ABSTRAK
Si Cepot Giri Harja 3 memiliki anasir sufisme yang tersublimasikan melalui wujudnya. Anasir sufisme ini menjadi bagian yang imanem di dalam profanitas wayang golek purwa sebagai sebuah paradoks yang mempertahankan dualitas keseniannya sebagai sebuah tontonan dan tuntunan. Anasir sufisme si Cepot Giri Harja 3 merupakan sebuah entitas yang tercipta dari pelbagai macam konsep sufi yang ada di dalam jagat mistikisme Islam. Akan tetapi, di dalamnya terdapat pula perkelidanan antara bentuk-bentuk kebudayaan lokal: sinkretisme. Hal tersebut dijelaskan melalui konsep wacana, pengetahuan, dan kekuasaan Michel Foucault, karena anasir sufisme si Cepot tersebut melahirkan sebuah pengetahuan baru yang terbentuk dari pelbagai macam entitas di atas. Foucault menyebutnya sebagai Arkeologi Pengetahuan. Anasir sufisme si Cepot secara khusus dianalisis dengan menggunakan teori hermeneutik Paul Ricouer yang menganalisis pelbagai simbol di dalam wujudnya. Dari analisis yang dilakukan, anasir sufisme si Cepot bersifat relasional karena terbentuk dari pelbagai macam konsep sufi dan mistisme Sunda juga Jawa. Sehingga secara eksistensialis,hal-hal tersebut tidak dapat dipisahkan karena secara fundamen menghadirkan anasir sufisme yang tersebar di di dalam maujud dan wujudnya.
\end{abstract}

Kata Kunci: Panakawan, Sufisme, Wujud, Arkeologi Pengetahuan, Hermeneutik.

\begin{abstract}
Si Cepot Giri Harja 3 has a Sufism element sublimed through its entity. This Sufism element turns into an immanent part in profanity of golek purwa puppet as a paradox that maintains its artistic duality either as a show or as guidance. The Sufism element of si Cepot Giri Harja 3 is an entity created from various sufistical concepts in Islamic mysticism field. However, there is also a discourse among indigenous cultural forms: syncretism. It is explained through Michel Foucault's concept of discourse, knowledge, and power, since the Sufism element of si Cepot creates a new knowledge composed of various entities stated before. Foucault calls this as the archeology of knowledge. Sufism element of $s i$ Cepot is specifically analyzed using hermeneutic theory of Paul Ricouer who analyzed various form of symbols. Based on the analysis, Sufism element of si Cepot tends to be relational as it is created from various Sufistic and mysticism concepts in Sunda and Java. Therefore, existentially, all explained above cannot be separated since it fundamentally creates Sufism element identified in its entity.
\end{abstract}

Keywords: Panakawan, Sufism, Entity, The archeology of knowledge, Hermeneutics. 


\section{PENDAHULUAN}

Orang Sunda memang ditakdirkan untuk banyak tertawa bahkan sampai terbahak-bahak hingga lupa dengan alasan mereka tertawa. Orang Sunda juga tidak dapat dipisahkan dari guyonannya yang khas: satir, sarkastik, dan sedikit genit, sedikit mesum tetapi tidak sepenuhnya kosong apalagi bolong karena selalu ada sesuatu di baliknya. Sesuatu yang secara implisit mengkritisi sesuatu yang lainnya, yang dekaden, yang mendestruksi tata adat dan adab dari karuhun (leluhur). Bisa jadi, karena hal itu pula, Giri Harja 3-salah satunya karena ulah si Cepot-meraih popularitas yang gemilang di tatar Sunda. Si Cepot adalah keniscayaan di atas yang menghadirkan gurauan juga guncangan yang membuat khalayak tertawa terbahak kemudian terdiam beberapa saat; menundukan kepala mengingat segala laku yang pernah diperbuat. Di balik si Cepot, di balik Giri Harja 3 yang kesohor hingga ke seantero Nusantara adalah Alm. Asep Sunandar Sunarya, seorang Dalang karismatik yang visioner dan revolusioner.

Visionerisme dan revolusionerisme Asep Sunarya Sunandar merupakan semacam relevansi dari pepatah karuhunnya, "Mi Indung ka waktu, mi Bapak ka zaman." Pepatah yang menganjurkan bahkan semacam mewajibkan orang Sunda untuk meladeni segala bentuk perubahan zaman dengan kesadaran penuh sehingga tidak terbawa arus yang kadangkala implusif. Dari kesadaran itulah, visi Asep Sunarya Sunandar terbentuk dan melalui Giri Harja 3. Asep Sunarya Sunandar merevolusi dunia pewayangan-nya. Asep Sunarya Sunandar melakukan semacam negosiasi kultural yang berhasil mempopulerkan wayang golek purwa- nyake dalam budaya massa yang populis tetapi tidak mereduksi nilai-nilai etika, estetika, dan spiritual yang ada di dalamnya secara/terlalu fatalistik. Tetapi, keberhasilannya tersebut tidak melulu diapresiasi secara positif bahkan beberapa sesepuh di dalam dunia pewayangan golek purwa merasa keberatan dengan visi Asep Sunarya Sunandar.

Tetapi keberatan-keberatan tersebut dijawab oleh Asep Sunarya Sunandar dengan menyuguhkan karya-karya gemilangnya yang secara perlahan membuat pamor Giri Harja 3 kesohor dan menjadi salah satu kelompok kesenian wayang golek purwa yang disegani dan dihormati di Nusantara. Seperti yang telah disebutkan di atas, si Cepot merupakan salah satu penyebab meroketnya popularitas Giri Harja 3. Kehadiran si Cepot bahkan lebih ditunggu-tunggu daripada kehadiran dewa-dewi Swargaloka dan para satria Amartapura. Si Cepot memiliki posisi yang sangat fundamental di dalam pelbagai lakon yang dibawakan oleh Giri Harja 3. Karena si Cepot adalah penyambung lidah yang paling tepat untuk menyampaikan tuntunan di dalam tontonan karena si Cepot selain dapat menghadirkan tawa yang membahana juga memiliki sifat yang sangat egaliter sehingga khalayak tidak akan merasa digurui ketika si Cepot menyampaikan kritikan keras terhadap khalayaknya sendiri.

Tuntunan dalam tontonan adalah kewajiban moral Giri Harja 3 dalam praktik berkeseniannya. Asep Sunarya Sunandar menyadari betul hal itu karena secara historis wayang adalah salah satu media dakwah yang di gunakan oleh para Wali (Walisanga) untuk menyebarkan agama Islam. Oleh karena itulah, tuntunan yang disampaikan didominasi oleh dakwah 
Islami setelah atau sebelum atau di dalam senda gurau. Asep Sunarya Sunandar tahu betul gurauan adalah salah satu cara untuk menyampaikan dakwah Islami kepada khalayak tanpa terkesan terlalu menggurui karena Asep Sunarya Sunandar tahu khalayak kekinian tidak sudi digurui. Mereka, khalayak, datang melihat Giri Harja 3 untuk hiburan, melepas kepenatanmelepas lelah yang mendera pikiran bukan untuk digurui. Melalui si Cepot, Asep Sunarya Sunandar berhasil menyublimasikan dakwah Islami tersebut ke dalam gaya komunikasi yang penuh dengan guyonan segar. Selain itu, wujud si Cepot Giri Harja 3 pun terlihat lebih dinamis-bahkan kadangkala atraktifdengan wajah lucu yang ngeyel menggemaskan itu sehingga tidak membuat jenuh yang melihatnya.

Tuntunan Islami yang disampaikan oleh Asep Sunarya Sunandar melalui si Cepot dapat dilihat dari dua hal yang saling melengkapi, bersinggungan, terhubung, dan tidak dapat dipisahkan begitu saja. Pertama, tuntunan Islami yang bersifat normatif (etika/syariat) dan kedua tuntunan yang bersifat hakikat (esoteris/mistikisme/ sufisme) - tersurat dan tersirat. Keduanya saling memintah hal juga ikhwal tidak dapat terpisahkan karena secara holistik mengkonstruksi tuntunan berdasarkan ajaran agama Islam lebih utuh. Tetapi, tuntunan kedualah, tuntunan yang bersifat hakikat yang menarik untuk diteliti, karena secara implisit mengindikasikan penyampaian ajaran agama Islam dalam konteks mistisnya (yang selanjutnya akan disebut sufisme) - hal ini sangatlah wajar mengingat wayang sebagai media dakwah Islam yang digunakan oleh Walisanga banyak mengkawinkan sufisme dan mistikisme Jawa dan Hindu-Budha ke dalamnya. Upaya tersebut dilakukan untuk dapat merangkul khalayak secara massif. Giri Harja 3 tidak saja mengindikasikan sufisme tersebut secara lisan tetapi ditampilkan pula secara simbolik di dalam wujud para tokohnya termasuk di dalam wujud si Cepot. Menariknya, indikasi sufisme di dalam wujud si Cepot tidak banyak diketahui oleh khalayak luas padahal indikasi sufisme di dalamnya secara relasional menjadi sesuatu yang fundamen karena telah membentuk karakter si Cepot yang khas Giri Harja 3-yang nyunda yang Islam yang nyufi.

\section{TINJAUAN TEORITIK}

Wujud dalam hermeneutik adalah teks dan dapat dipandang secara polisemis, sehingga penafsiran menjadi masalah sentral. Jadi, hermeneutik bertujuan untuk verstehen (memahami) melalui metode abduksi, bukan hanya menafsirkan. Interpretasi (penafsiran) selalu merupakan rekonstruksi makna sebuah teks, atau menurut istilah Ricoeur, reproduksi (Hoed, 2011:93). Paul Ricoeur, dalam hal ini memandang hermeneutik tidak hanya sebagai teori interpretasi terhadap simbolsimbol saja, akan tetapi menambahkannya sebagai "perhatian kepada teks". Teks sebagai penghubung bahasa isyarat dan simbol-simbol dapat membatasi ruang lingkup hermeneutik karena budaya oral (ucapan) dapat dipersempit (Sumaryono, 1999:107). Pernyataan tersebut secara konsentrik menjadikan teks sebagai pusat analisisnya. Bagi Ricoeur, hermeneutik memiliki dua tugas utama, yang pertama adalah mencari dinamika internal yang mengatur struktural kerja di dalam sebuah teks (Sumaryono, 1999:107). Kedua adalah mencari daya yang dimiliki kerja teks itu untuk memproyeksikan diri ke luar dan memungkinkan "hal" nya teks itu muncul ke permukaan (Sumaryono, 1999:107). 
Paul Ricoeur mendefinisikan hermeneutik sebagai, teori pengoperasian pemahaman dalam hubungannya dengan interpretasi terhadap teks (Semaryono, 1999:107). Teks dalam pandangan Ricoeur bermakna plural menurut konteksnya. Ia menyebutnya sebagai polisemi, yaitu kebermaknaan tekstual menurut kontekstualnya yang bersangkutan. Sehingga, sebuah teks, menurut Ricouer pada dasarnya otonom untuk melakukan "dekontekstualisasi", baik dari sudut pandang sosiologis maupun psikologis, serta untuk melakukan "rekontekstualisasi" secara berbeda di dalam tindakan membaca ("dekontekstualisasi" = proses 'pembebasan' dari konteks; "rekontekstualisasi" proses masuk kembali ke dalam konteks). (Sumaryono, 1999:109).

Dekontekstualisasi dan rekontekstualisasi merupakan sebuah dikotomi antara penjelasan dan pemahaman. Keduanya mengindikasikan sebuah pemahaman yang memiliki keberawalan karena keduanya akan menghasilkan sebuah proses yang dialektis. Otonomi teks ada tiga macam: intensi atau maksud pengarang, situasi kultural dan kondisi sosial pengadaan teks, dan untuk siapa teks itu dimaksudkan. Atas dasar otonomi inilah, maka yang dimaksudkan dengan "dekontekstualisasi" adalah bahwa teks "melepaskan diri" dari cakrawala intensi yang terbatas dari pengarangnya (Sumaryono, 1999:109). Tahap ini merupakan tahap penjelasan dari sebuah teks. Ketika telah sampai pada tahap penjelasan ini, maka selanjutnya adalah tahap pemahaman "rekontekstualisasi".

Menurut Ricoeur ada tiga langkah pemahaman, yaitu langkah simbolik, atau pemahaman dari simbol ke simbol. Langkah kedua adalah pemberian makna oleh simbol serta 'penggalian' yang cermat atas makna. Langkah ketiga adalah yang benar-benar filosofis, yaitu berpikir menggunakan simbol sebagai titik tolaknya (Sumaryono, 1999:111). Ketiga langkah pemahaman tersebut sangat erat kaitannya dengan langkah-langkah pemahaman akan bahasa: semantik, reflektif, dan eksistensial atau ontologis. Langkah semantik adalah pemahaman pada tingkat ilmu bahasa murni; pemahaman reflektif adalah pemahaman pada tingkatan yang lebih tinggi, yaitu yang mendekati ontologis; sedang langkah pemahaman eksistensial atau ontologis adalah pemahaman pada tingkat being atau keberadaan makna itu sendiri (Sumaryono, 1999:111).

Bagi Paul Ricoeur, teks di tempatkan pada posisi utama, yang sentral. Baginya, teks adalah perwujudan dari apa yang disebutnya sebagai "speech" (basaha lisan). Jadi, teks menurut Ricoeur merupakan turunan dari speech yang memiliki sistem acuannya sendiri sehingga tidak lagi terikat oleh sistem speech yang tunggal. Karenanya, teks harus dijelaskan melalui otonomisasinya dan dipahami dengan langkah-langkah yang telah disebutkan diatas. Hal tersebut merupakan konsekuensi logis dari teori hermeneutiknya yang mencari pemahaman dari penjelasan dan interpretasi (Hoed, 2011:94).

Dalam konteks wujud si Cepot, teori hermeneutik Paul Ricoeur digunakan sebagai teori yang menganalisis wujudnya untuk menjelaskan anasir sufistik yang ada di dalamnya yang dihasilkan dari abstraksi keberbudayaan yang di dalamnya yang terdiri dari pelbagai macam simbol yang saling bertautan satu dan yang lainnya; memintal hal ikhwal dan harus dipahami sebagai sebuah pemahaman yang 
mempunyai subtansibilitas yang didasarkan atas eksistensinya.

\section{SUFISME, WAYANG GOLEK PURWA, DAN PANAKAWAN GIRI HARJA 3}

Wayang golek purwa memiliki kecenderungan sufistik yang tidak bisa ditampikan. Karena secara historis memiliki relasi yang kuat dengan penyebaran agama Islam oleh para Wali. Akan tetapi kecenderungan sufistik wayang golek purwa menjadi berbeda dengan kecenderungan sufistik yang terdapat di dalam pewayangan Jawa. Perkembangan sufisme di tatar Sunda menunjukan bahwa visi sufisme Ibn Arabi yakni wujudiyah kalah pamor oleh visi sufisme transendentalis AlGhazali-visi-visi sufisme yang lebih mengedepankan aspek syariat, sehingga visi sufistik di dalam konstelasi ajaran agama Islam di tatar Sunda mengalami perkembangan yang sangat unik. Walaupun visi sufisme wujudiyah Ibn Arabi sepertinya kalah pamor tetapi subtansi sufisme di dalam wayang golek purwa memiliki visi sufisme wujudiyah Ibn Arabi yang sangat kentara. Hal ini tidak mengherankan mengingat visi sufisme Ibn Arabi merupakan subtansi dari (hampir) visi sufsime yang berkembang di dalam mistikisme Islam. Hal tersebut berpengaruh pula terhadap kecenderungan sufisme yang terdapat di dalam kesenian wayang golek purwa yang mengadopsi kedua visi sufisme. Keduanya menjadi manunggal sebagai entitas yang berbeda.
Panakawan adalah medium dalam menyublimasikan sufisme di dalam jagat pewayangan dan salah satunya ditampilkan melalui wujudnya. Sejak awal mula kelahirannya, wujud panakawan memang terlihat nyaris tidak membentuk wujud itu sendiri; wujud mereka adalah bentuk destruksi wujud manusia tetapi dalam destruksi, dalam wujud yang kaosada sebuah kebermaknaan yang terbentuk dari pelbagai macam entitas paradoksial yang memiliki keutamaan-keutamaan manifestasial dari subtansi yang memiliki dimensi transendensial yang teramat fundamen. Pada mulanya, panakawan sama sekali tidak terdapat dalam kitab Ramayana yang ditulis oleh Valmiki (Walmiki) maupun Mahabarata yang ditulis oleh Vyasa (Wiyasa). Tokoh-tokoh ini asli Indonesia (Wangi, 1999:971). Untuk kali pertama, para tokoh panakawan muncul sekitar abad ke-12 dalam wiracarita Gatotkacasrya dan Sudhamala. Kemunculan para tokoh panakawan merupakan sebuah bukti sinkretisme antara kebudayaan asing dan kebudayaan lokal. Dikatakan sinkretisme karena masuknya tokoh-tokoh panakawan kedalam alur cerita telah merubah konsep religi dan filsafat dari Hindu murni menjadi religi dan filsafat Jawa (Wangi, 1999:791). Perubahan tersebut totalistik akan tetapi tidak totaliter: ada sebuah antara di dalamnya, sebuah paradoks ${ }^{1}$. Paradoks yang mewujud ke dalam wujudnya "tak membentuk" wujud. Ada sesuatu yang nyeleneh dalam konteks estetika tertentu. Estetika menjadi relative. Akan tetapi, dibalik wujudnya yang "tak membentuk" tersebut ada dua hal yang dapat dipahami, yang pertama wujud panakawan dapat

\footnotetext{
${ }^{1}$ Jakob Sumardjo. Estetika Paradoks. “...Batas bersifat paradoksal, karena memisah namun menghubungkan juga, akibat tidak adanya jarak antar kedua entitas. kalau ada batas pun amat tipis. Batas ini merupakan entitas ketiga yang menghubungkan sekaligus memisahkan dualisme antagonistik entias-entitas lainnya. itulah sebuah batas, adalah sakral karena nilai paradoksialnya." (Bandung: Sunan Ambu Press, 2010), 370.
} 
dipahami sebagai sebuah manifestasi transendensial yang merepresentasikan subtansialitas dari sebuah ajaran agama tertentu-misalnya Islam dengan sufismenya. Kedua, wujud panakawan merupakan sebuah simbol perlawan yang merepresentasikan masyarakat akar rumput yang mencoba untuk "melawan" sebuah "rezim" tertentu².

Begitu pula dengan panakawan Giri Harja 3 yang tidak lekang dari pengaruh di atas. Akan tetapi, memiliki diferensiasi yang cukup signifikan walaupun secara subtansial kemungkinan besar masih memiliki persamaan yang fundamen sebagai sebuah ekspresi spiritualitas. Di dalam Arkeologi Pengetahun Michel Foucalt inilah yang disebut sebagai lingkaran referensial. Dimana pelbagai macam bentuk entitas keberbudayaannya tersublimasikan ke dalam sebuah bentuk yang relatif "baru". Merujuk kepada pandangan Foucault, panakawan Giri Harja 3merupakan sebuah bentuk wacana yang di dalamnya dipengaruhi oleh kuasa dan pengetahuan.

Wujud Semar, misalnya, secara deskriptif dapat digambarkan sebagai berikut: Berwajah putih dengan muka yang terlihat seperti anak-anak; tidak sedang tersenyum tidak juga sedang bersedih; kuncung Semar terlihat sebagai satusatunya rambut yang menempel di atas kepalanya. Semar Berkulit hitam pekat, bertubuh bungkuk, dengan buah dada yang besar serta berperut besar dan berpantat besar. Secara manifestasial wujud Semar memiliki nilai-nilai yang merepresentasikan kebaikan pada diri manusia. Semar sering ditampilkan dalam pelbagai bentuk busana yang berbeda-beda. Akan tetapi, perbedaan tersebut tidak menyentuh subtansi Semar sebagai sebuah entitas kebernilaiian dan hanya sekedar pelengkap estetis saja.

Begitu pula dengan wujud panakawan lainnya yang mempunyai kecenderungan sewujud di dalam wujudnya. Oleh karenanya, berdasarkan beberapa hal di atas, ada beberapa hal yang mengindikasikan bahwa wujud Semar dan panakawan Giri Harja 3 lainnya memiliki semacam dimensi yang paradoksial; yang mistik, yang subtan, dan yang termanifestasikan sebagai sebuah bentuk simbolik manusia yang sempurna tidak sempurna. Dikatakan paradoksial karena ketidaksempurnaan wujud Semar justru adalah kesempurnaan wujudnya yang liyan, yang subtan, yang hakiki. Hal tersebut, secara korelatif mempengaruhi struktur kewacanannya dan relasi sosialnya. Sehingga, wujud panakawannya secara subjektif dipengaruhi oleh pelbagai macam represi dan dominasi dari sang dalang. Sejalan dengan apa yang diyakini oleh Foucault bahwa, kebudayaan (kebudayaan) tidak terbentuk dari garis keturunan dan warisan turun-temurun yang dapat dipahami di bawah nama tradisi (Jenks, 2013:213). Jika demikian, sebagai sebuah abstraksi dari kebudayaan merupakan sebuah bentuk lingkaran referensial yang

2 Goenawan Mohamad. Punakawan. "Dalam rezim estetika itu, yang "halus" ditaruh di tempat yang diunggulkan. Yang "halus" ditandai keapikan aristokratik: anggun, gemulai, rapi, ramping (bukan kurus kering)tanda fisik dan kejiwaan orang yang tak harus bekerja di lingkungan yang keras dan kotor, cukup punya waktu senggang dan kekuasaan hingga tak perlu menyampaikan kehendak dengan suara tak sabar. Mereka juga orangorang yang cukup gizi hingga biasa makan dengan kalem, tak tampak gelojoh. Adapun mereka yang tak punya ciriciri itu dianggap hina, bahkan sebagai musuh: orang seberang, raksasa, atau Kurawa. Jelas rezim estetik itu terkait dengan kekuatan dan posisi politik.Mahabharata adalah epos para pangeran di sebuah masyarakat yang ditata dengan klasifikasi yang yakin. Ketika epos itu berkembang di Jawa (mungkin di abad ke-7), klasifikasi dari India itu tak sepenuhnya diterima."Melalui www.tempo.com/caping [10/10/11]. 
saling terhubung melalui bagian-bagain terkecilnya sebagai pembentuk eksistensinya.

Secara subtansi, wujud panakawan Giri Harja 3 memiliki kecenderungan untuk ditafsirkan ke dalam wacana keagamaan terutama mistisme. Artinya, di dalam wujud mereka, terdapat pelbagai macam kecenderungan mistik, khususnya mistisme di dalam Islam atau sufisme. Merujuk pernyataan Dadan Sunandar Sunarya perihal Semar, "Asal kata Semar dari Samar atau Smar yang mengandung arti "tidak jelas", "ada tapi tiada", terasa tapi tidak diketahui "keberadaannya". Sem, penganken-nganken, Mar, menyemaraken dzatna alam; bersaksi atas baik dan buruknya alam. Itulah Semar, bersaksi atas baik dan buruknya alam. Kecenderungan mistikisme terlihat jelas di dalam pernyataannya tentang Semar; ketidakberadaan merupakan sebuah indikasi sufisme yang sangat subtansialkhususnya mistikisme Islam, sufisme.

Kecenderungan sufisme di dalam wujud Semar dimiliki pula oleh para tokoh panakawan lainnya termasuk di dalam wujud si Cepot sebagai sebuah bentuk perkelidanan subjektivitas yang ada di dalamnya; yang membentuk sebuah kuasa dan pengetahuan di dalam wujud panakawannya. Hal tersebut berkesesuaian dengan pendapat Foucault tentang Arkeologi Pengetahuan; bagi Foucault, segala sesuatu saat ini bersifat subyektif, oleh sebab itu pengetahuan tidak mungkin dipisahkan dari kekuasaan, dimana secara manifestasial merupakan sebuah keluaran bagi sebuah "institusi pengetahuan" yang pada akhirnya justru menghasilkan pengetahuan yang mendukung sistem "kekuasaan". Di dalam konteks wujud panakawan Giri Harja 3 pengetahuan sang dalang berkelidan dengan pengetahuan yang terdapat di dalam wujud panakawannya akan tetapi, dengan kuasa sang dalang, pengetahuan tersebut mengalami sebuah perkelidanan kembali sehingga melahirkan panakawan yang kita kenal hingga hari ini.

\section{ANASIR SUFISTIK DI DALAM WUJUD SI CEPOT GIRI HARJA 3}

Ricoeur menyatakan bahwa tugas utama hermeneutik ialah di satu pihak mencari dinamika internal yang mengatur struktural kerja teks itu untuk memproyeksikan diri ke luar dan memungkinkan "hal"nya teks itu muncul ke permukaan. (2000:115) Untuk itu, definisi yang diajukan oleh Ricoeur tentang hermeneutik harus dipatuhi, yakni mengoperasikan pemahaman dalam hubungannya dengan interpretasi terhadap teks. Teks adalah segala sesuatu yang dapat dibaca. Wujud dalam hal ini adalah sebuah teks karena dapat dibaca. Setiap membaca sebuah teks, teks tersebut akan selalu berhubungan dengan masyarakat, tradisi ataupun aliran yang hidup dari bermacammacam gagasan. Sebuah teks pada dasarnya bersifat otonom untuk melakukan dekontekstualisasi (proses pembebasan diri dari konteks), baik dari sudut sosiologis maupun psikologis, serta untuk melakukan rekontekstualisasi (proses masuk kembali ke dalam konteks) secara berbeda didalam tindakan membaca. Dikotomi antara penjelasan dan pemahaman itu tajam, yaitu untuk memahami sebuah percakapan kita harus kembali pada struktur permulaannya. Kebenaran dan metode dapat menimbulkan proses dialektis (Ricoeur, 2004:96).

Pemahaman tentang teks menjadi sangat penting dalam menerapkan teori 
hermeneutika Paul Ricouer. Ricoeur menjelaskan bahwa wacana adalah, "Any discourse fixed by writing." 3 Teks adalah bahasa yang digunakan untuk berkomunikasi. Dengan demikian, wujud si Cepot adalah juga sebuah teks karena memiliki simbol-simbol untuk melakukan sebuah tindakan komunikasi. Sebagai sebuah teks, wujud si Cepot layak untuk diinterpretasikan dengan menggunakan teori hermeneutik Paul Ricoeur. Interpretasi tersebut dilakukan untuk menganalisis indikasi-indikasi sufisme yang ada di dalamnya.

Wujud si Cepot akan memunculkan interpretasi yang berbeda-beda karena, sebagai sebuah teks wujudnya tidak pernah terlepas dari bahasa, Heidegger menyebutkan bahasa sebagai dimensi kehidupan yang bergerak yang memungkinkan terciptanya dunia sejak awal. Oleh karena itu, sebagai sebuah teks, proses memperantarai dan menyampaikan pesan harus mencakup tiga arti yang terungkap di dalam tiga kata kerja yang saling berkaitan satu dengan yang lain: mengkatakan, menerangkan, dan menerjemahkan (Poespoprodjo. 1987:192).

Pernyataan di atas tidak berarti bahwa suatu teks harus selalu dijelaskan sesuatu di luar teks. Sesuatu dari luar tersebut hanya relevan jika dikenali sebagai sesuatu yang dikenalidi dalam teks tersebut. Pengetahuan tentang sesuatu tersebut dapat membantu dalam memahami teks lebih baik. Hal tersebut menjelaskan bahwa interpretasi makna adalah persoalan konteks belaka. Seluruh penginterpretasian ditujukan untuk menyediakan ruang pemahaman baru. Teks tidak begitu saja dapat dipahami, dibutuhkan situasi pemahaman agar dua hal tersebut bertemu-yakni interpretator melangkah masuk ke dalam lingkaran teks yang ada secara holistik.

Interpretasi berfungsi menunjuk arti, mengkatakan, menuturkan, mengungkapkan, membiarkan tampak, membukakan sesuatu yang merupakan pesan realitas. Metode yang digunakan adalah yang memungkinkan realitas memberita, mengkatakan dirinya, jauh dari segala distorsi dan disonansi. Ukuran kebenaran interpretasi adalah interpretasi yang bertumbuh. berpangkal pada evidensievidensi objektif; pada hal-hal yang memang sesungguhnya dapat diidentifikasi. Dengan demikian interperatsi bukan monolog melainkan dialog. Dialog adalah proses yang menginterpretasikan realitas yang terartikulasikan. Mewartakan realitas yang tidak seketika menjadi final tetapi juga sebuah proses. Maka interpretasi selalu melakukan tindakan (re)interpretasi terhadap dirinya sendiri.

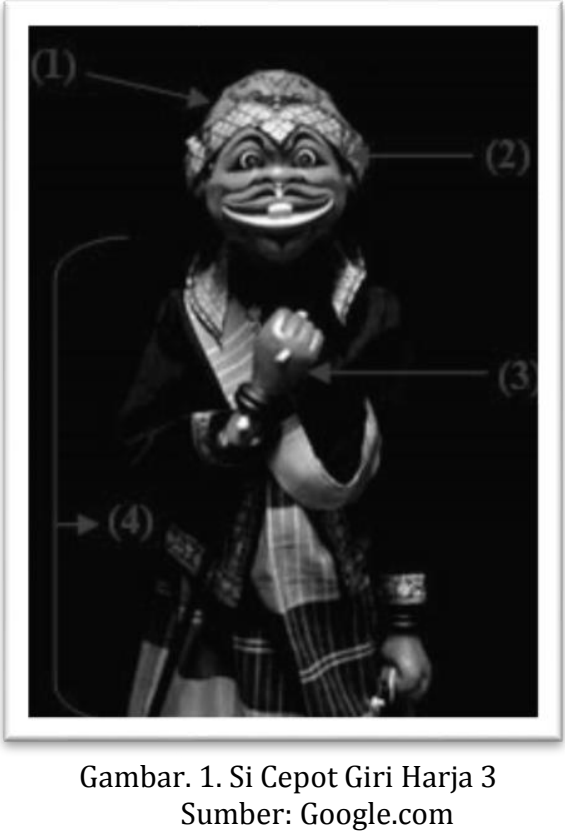

\footnotetext{
3 Paul Ricoeur. Hermeneutics and the Human Sciences Essays on Language, Action and Interpretation. (Cambrige:
} Cambrige University Press, 1982), 145. 


\section{A. Analisis Tahap Dekontekstualisasi}

\section{Teks: Wujud Si Cepot}

Si Cepot berwajah mirip dengan Semar akan tetapi terlihat lebih jenaka dengan senyuman mengembang lebar. Si Cepot memiliki kumis yang tipis, satu gigi di depan bagian atas, dan kulit yang berwarna merah. Jari-jemarinya selalu terlihat mengepal. Berbusana khas Sunda-pada gambar di atas menggunakan pangsi berwarna hitam dengan ragam hias pada titik-titik tertentu-dengan ikat kepala Sunda: Barangbang Semplak bermotif batik, berselendang sarung, dan bersarung warna ungu dengan motif kotak-kotak.

\section{Intensi Penulis}

Busana si Cepot terbilang cukup variatif dengan pelbagai elemen estetis yang berganti-ganti, namun secara subtansi tetap menggunakan busana urang Sunda secara umum: iket kepala, pangsi, sarung, dan kadang-kadang juga bedog. Dari segi teknis, busana, dan karakteristik, si Cepot terbilang cukup otentik dari si Cepot yang lainnya. Subtansi wujudnya tetap dipertahankan, yakni tetap memiliki kemiripan dengan Semar, berwarna kulit merah menyala, sesuai dengan nama lainnya: Sastrajingga atau Astrajingga. Si Cepot, boleh disebut sebagai merupakan magnum corpusnya Giri Harja 3 (Asep Sunandar Sunarya) karena telah berhasil mensublimasikan daya kreativitasnya termasuk ideologi-ideologi ke dalamnya dan digemari oleh khalayak luas-bahkan ditiru oleh banyak dalang dari kelompok wayang golek purwa lainnya.

\section{Lingkungan Teks}

Wujud si Cepot tidak dilahirkan dari suatu lingkungan yang steril. Banyak sekali pengaruh yang bersifat kultural di dalamnya, terutama pengaruh budaya Sunda. Hal yang paling menarik adalah pengaruh Jawa di dalam wujud si Cepot tidak sebesar pengaruhnya terhadap wujud Semar. Mengingat wujud Semar memiliki pakem-pakem tertentu yang bersifat khas sedangkan si Cepot tidak terlalu terikat dengan pakem-pakem sepertihalnya bapaknya. Hal ini menjadikan kreativitas ASS dapat diterjemahkan ke dalam wujud si Cepot secara utuh. Dapat dikatakan bahwa adalah si Cepot yang sepenuhnya representasi urang Sunda. Karena dalam wujudnya dapat dilihat pelbagai macam bentuk kebudayaan Sunda, semisal dari karakter wajah dan busana yang digunakannya. Wujudnya secara pragmatis dan kemungkinan besar secara subtansi dipengaruhi oleh kreativitas atau, dengan kata lain subjektivitas sang empunya, yakni Asep Sunandar Sunarya.

Subjektivitas dapat diartikan sebagai sebuah daya kreativitas yang mewujud menjadi sesuatu yang relatif lebih baru yang didasarkan atas perkelidanan antara diri dan lingkungan di mana diri tersebut berada. Sebagai urang Sunda, tentu, Asep Sunandar Sunarya paham bagaimana wujudurang Sunda harus ditampilkan. Hal inilah yang membuat wujud si Cepot menjadi sesuatu hal yang niscaya dalam konteks dinamika keberbudayaan di dalam pewayang purwa tatar Sunda.

\section{Pembaca Teks}

Dengan popularitas yang luar biasa, si Cepot mau tidak mau, suka tidak suka, harus mampu merangkul dua kategori besar khalayak wayang golek purwa-Si Cepot harus mampu mengembangkan dinamika 
kebudayaan Sunda yang sedang terjadi ke dalam konteks global, sehingga si Cepot yang lokal mampu untuk dikonsumsi secara global. Artinya, self-identity, di dalam diri si Cepot harus menaklukkan konstani zaman agarsebagai sebuah wacana, si Cepot terlihat memiliki pesona (kebudayaan) lokal yang kuat, sekaligus mampu untuk merangkul pelbagai kompleksitas keberbudayaan lainnya. Dengan demikian, si Cepot akan menjadi sebuah wacana yang dapat ditafsirkan oleh khalayak yang plural. Hal tersebut sudah dilakukan oleh Asep Sunandar Sunarya dan para pewarisnya. Cultural distance antara khalayak dengan si Cepot mampu teratasi. Dalam konteks wujud, si Cepot memang memiliki keuntungan yang sangat besar, dan oleh karena itu, setiap khalayak yang memiliki latar budaya yang berbeda akan sedikit mudah mengintrepretasikan si Cepot sebagai panakawan yang jenaka.

\section{B. Analisis Tahap Rekontekstualisasi}

\section{Hasil Dekontekstualisasi Si Cepot}

Secara dekontekstualisasi, diketahui bahwa wujud $\mathrm{Si}$ Cepot memiliki kecenderungan yang sama seperti Semar. Oleh sebab itu, wujud si Cepot dapat diinterpretasikan ke dalam pelbagai wacana. Salah satunya, sufisme.

\section{Semantik}

Wujud si Cepot dapat dibagi ke dalam 4 kelompok wujud, yakni: (1) Iket kepala, (2) Wajah termasuk giginya, (3) Tubuh dan warna kulitnya, dan tangan yang terlihat mengepal, (4) Busana yang digunakannya. Secara semantik, (1) Si Cepot memakai iket $^{4}$ kepala khas Sunda dengan motif batik yang berwarna kuning, kemungkinan besar iketnya berjenis Barangbang Semplakyang telah disesuaikan. (2) Wajah si Cepot yang berwarna merah memiliki kemiripan dengan wajah Semar. Akan tetapi, wajah si Cepot terlihat lebih tegas, artinya lebih memperlihatkan ekspresi yang jelas: ekspresi kegembiraan dengan senyum lebarnya. Dari senyum yang lebar itu terlihat satu gigi pada mulut bagian bawahnya, persis seperti Semar. (3) Secara anatomis, tubuh si Cepot yang seluruhnya berwarna merah lebih sempurna dibandingkan dengan tubuh Semar. Kedua tangan si Cepot terlihat mengepal, membentuk lingkaran, atau dapat juga dikatakan angka 0 (nol). (4) Busana yang digunakannya adalah varian busana khas Sunda yang berwarna hitam dengan beberapa elemen estetis berwarna putih bermotif kotak-kotak serta menggunakan sarung yang berwarna unggu.

\section{Reflektif}

${ }^{4}$ Suciati. Karakteristik Iket Sunda di Bandung dan Sumedang Periode Tahun 1968-2006. "Iketmerupakan jenis tutup kepala tradisional yang terbuat dari kain dan dipakai dengan teknik tertentu seperti dilipat, dilipit, dan disimpulkan sebagai pengikat akhir. Iket dipakai oleh pria dari berbagai kalangan baik ulama, penghulu, pegawai pemerintahan, masyarakat golongan bawah, mulai dari anak usia sekolah sampai orang tua, dan juga bangsawan. Iket disebut juga totopong yang terbuat dari kain atau boéh atau mori. Totopong merupakan bentuk iket yang lebih rapi. Dulu boéh diartikan kain. Ada yang disebut boéh alus (kain halus), boéh siang (kain merah) dan boéh larang atau kain yang mengandung kekuatan. Sekarang kata boéh berarti kain putih, yang menurut kamus Umum Basa Sunda: boéh nyaeta lawon bodas tina kapas (boéh adalah kain putih dari kapas). Kain yang lebih halus dari boéh disebut kaci. Kata boéh sekarang ini mengalami penyempitan makna menjadi kain putih yang dipakai untuk membungkus mayit atau mayat atau yang dikenal dengan kain kafan. Kain untuk iket Sunda selain menggunakan batik, pada jaman dahulu sebelum mengenal batik menggunakan kain polos yang disebut hideungan (kain berwarna hitam) yang dikenal dengan nama Sandelin. Kain ini dapat pula dipakai untuk celana panjang, kamprét, dan calana pangsi." (ITB J. Vis. Art \& Des., Vol. 2, No. 3, 2008), 239. 
(1). Iket secara harafiah dapat diartikan sebagai penutup kepala yang dapat melindungi si penggunanya dari pelbagai macam hal. Misalnya melindungi si penggunannya dari panas matahari. Selain itu, dalam konteks filosofis, iket kepala juga berfungsi sebagai pelindung diri dari pelbagai macam hal yang ada di muka bumi.

Bagi masyarakat Sunda, iket kepala mempunyai posisi yang cukup penting, selain berfungsi sebagai penutup kelapa, iket kepala Sunda memiliki nilai-nilai filosofis yang begitu subtansial. Artinya, iket kepala tidak bisa digunakan sembarangan karena merepresentasikan sesuatu bagi si penggunannya. Sebagai contoh, iket Julang Ngapak hanya boleh digunakan oleh pemuka agama kerajaan-pandita, atau resi. Begitu pula dengan jenis iket lainnya yang mempunyai peruntukan tersendiri bagi si penggunanya.

Di dalam ajaran agama Islam penutup kepala dikenal dengan nama surban. Sama halnya seperti masyarakat Sunda, di dalam ajaran agama Islam, surban memiliki peruntukan yang fungsional dan subtansial. Bahkan penggunaan surban bagi umat Islam hukumnya adalah sunnah karena dianjurkan oleh nabi Muhammad SAW. di dalam beberapa hadist $^{5}$. Dari penjelasan di atas, dapat dipahami bahwa kebudayaan Sunda dan ajaran agama Islam dalam konteks ini memiliki relasi yang subtansial. Misalnya, di dalam ajaran agama Islam surban sebagai ikat kepala juga merupakan penutup kepala yang berfungsi sebagai kelengkapan dalam beribadah. Di dalam shalat (dapat pula berfungsi) sebagai sajadah, yang pada hakikatnya membentuk relasi transendensialistik antara manusia dan Allah Swt. Bagi urang Sunda, iket dapat berfungsi sebagai penyambung silaturahmi -iket sebagai warisan budaya, sehingga sesama pewaris dapat melakukan interaksi dalam konteks apapun menyangkut keberbudayaan. Ada hubungan antar manusia di dalamnya. Dari kedua hal tersebut, secara Islami dapat dilihat relasi yang deterministik antara iket dan surban sebagai kesatuan yang subtansial di dalam wacana keberagamaan dalam keberagamaan. Keduanya memperlihatkan

\footnotetext{
5 Dalam sebuah riwayat yang bersumber dari Jabir dikemukakan: "Nabi saw memasuki kota Makkah pada waktu Fathu Makkah beliau mengenakan sorban hitam." (HR. At-Tarmidzi. Hadits ini diriwayatan oleh Muhammad bin Basyar, dari 'Abdurrahman bin Mahdi, dari Hammad bin Salamah. Hadits ini pun diriwayatkan pula oleh Mahmud bin Ghailan, dari Waki', dari Hammad bin Salamah, dari Abi Zubair, yang bersumber dari Jabir ra.). Kemudian,'Amr bin Huraits berkata: "Aku melihat sorban hitam di atas kepala Rasulullah saw." (HR. Tarmidzi. Diriwayatkan oleh Ibnu Abi 'Umar, dari Sufyan, dari Musawir al-Waraq, dari Ja'far bin 'Amr bin Huraits, yang bersumber dari bapaknya). Kemudian, Dalam sebuah riwayat yang bersumber dari Ibnu 'Umar ra. dikemukakan: "Apabila Nabi memakai sorban, maka dilepaskannya ujung sorbannya di antara kedua bahunya." Kemudian Nafi' berkata: "Ibnu 'Umar juga berbuat begitu." 'Ubaidullah berkata: "Kulihat al-Qasim bin Muhammad dan Salim, keduanya juga berbuat demikian." (HR. Tarmidzi. Diriwayatkan oleh Harun bin Ishaq al Hamdzani, dari Yahya bin Muhammad al-Madini, dari 'Abdul 'Aziz bin Muhammad, dari 'Ubaidullah bin 'Umar, dari Nafi', yang bersumber dari Ibnu 'Umar.). Kemudian, Ibnu 'Abbas ra. mengemukakan: "Sesungguhnya Nabi Muhammad berpidato di hadapan ummat. Waktu itu beliau mengenakan sorban, dan sorbannya terkena minyak rambut.” (HR. At-Tarmidzi. Diriwayatkan oleh Yusuf bin 'Isa, dari Waki', dari Abu Sulaiman, yaitu 'Abdurrahman bin Ghasail, dari Ikrimah, yang bersumber dari Ibnu 'Abbas). Selanjutnya, dari Amr bin Umayyah ra dari ayahnya berkata : Kulihat Rasulullah saw mengusap surbannya dan kedua khuffnya (Shahih Bukhari Bab Wudhu, Al Mash alalKhuffain). Kemudian, dari Ibnul Mughirah ra, dari ayahnya, bahwa Rasulullah saw mengusap kedua khuffnya, dan depan wajahnya, dan atas surbannya (Shahih Muslim Bab Thaharah). Kemudian, para sahabat sujud diatas Surban dan kopyahnya dan kedua tangan mereka disembunyikan dikain lengan bajunya (menyentuh bumi namun kedua telapak tangan mereka beralaskan bajunya krn bumi sangat panas untuk disentuh). saat cuaca sangat panas. (Shahih Bukhari Bab Shalat).Kemudian, Rasulullah saw membasuh surbannya (tanpa membukanya saat wudhu) lalu mengusap kedua khuff nya (Shahih Muslim Bab Thaharah), dan masih belasan hadits shahih meriwayatkan tentang surban ini. Melalui, http://alhadistonline.wordpress.com/surban. 27/03/14.
} 
hubungan manusia dengan Tuhannya dan hubungan manusia dengan sesamannyaHabluminallah dan Habluminannas. Bagi para sufi, iket atau surban atau penutup kepala mempunyai posisi yang penting, karena dengan menggunakan surban berarti mengikat pikirannya dari segala sesuatu selain daripada Allah Swt. Selain itu, surban juga menyimbolkan hasil pencapaian perjalanan spiritualnya mereka. Hampir semua guru sufi ${ }^{6}$ diketahui menggunakan surban. Si Cepot selalu menggunakan iketkemungkinan besar-Barangbang Semplak berwarna kuning dengan motif batik,iket Barangbang Semplak termasuk iket buhun, yakni telah ada di dalam masyarakat Sunda sejak zaman entah kapan. Iket Barangbang Semplak yang digunakan si Cepot merepresentasikan Urang Sunda kebanyakan (di dalam konteks historik), yang sebagian besar berprofesi sebagai petani. Dengan menggunakan iket tersebut si Cepot bersifat egalitarian, karena merepresentasikan masyarakat akar rumput. Dalam konsep sufisme hal tersebut dapat diartikan sebagai asketisme. Para petani di daerah Sunda memiliki dimensi mistik yang implisit. Misalnya, jika bertanya kepada seorang petani hendak pergi ke mana, biasanya akan dijawab, "Ah, biasa weh, jang, neangan nu euweuh!" Artinya "Biasa nak. Mencari yang tidak ada" (yang tiada). Mencari yang tidak ada (mencari yang tiada), ketiadaan merupakan hakikat segala sesuatu, dari yang tiada menjadi ada, dari yang ada menjadi tiada. Ada karena tiada dan tiada karena ada. Di dalam kosmologi Sunda ketiadaan merupakan subjek transendental yang tersublimasikan di dalam kesemestaannya. Yang tiada mewujudkaan realitas yang sesungguhnya ada. Dalam konsep sufi, pencaraian terhadap ketiadaan merupakan pencarian terhadap Tuhan itu sendiri. Pencarian terhadap hakikat segala sesuatu dengan cara meniadakan diri terlebih dahulu. Dalam pernyataan tersebut ada pemisahan, dan pengasingan diri sebagai subjek realitas yang sepenuh ada menjadi dis-subjektivitas terhadapnya sehingga benar-benar menjadi tiada dalam ketiadaan yang sesungguhnya ada sebagai realitas ultim. Ketika subjek menjadi tiada maka keadaan yang benarbenar ada akan terwujud di dalam ketiadaan tersebut. Seperti dalam konsep sufistik Abu Yazid Bistami melalui fana dan baqa-nya ${ }^{8}$.

${ }^{6}$ Hasan Al-Basri, Rabiah Al-Adawiyah, Abu Yazid Bistami, Ibn Sina, Al-Farabi, Imam Al-Ghazali, Al-Hallaj, Syekh al-Akbar Ibn Arab, dan lainnya.

${ }^{7}$ Berdasarkan hasil observasi penulis di beberapa tempat di Majalaya, Kab Bandung pada 10 Februari 2014. Penulis bertanya kepada lima orang petani pada lokasi-lokasinya: Sawah di sekitar Cihampelas, ladang ubi-ubian di Ciraab, sawah di Sayang, sekitar Curug Eti, dan sawah di Mantricina-yang berbeda-beda, tiga di antara para petani tersebut ketika ditanya mau kemana menjawab "mencari yang tidak ada". Walaupun para petani tersebut sama sekali tidak mengenal peneliti. "Bade angkat ka mana, Pak?" Tanya peneliti, "Ah biasa weh, jang, bade milarian nu euweuh!"

${ }^{8}$ Karen Armstrong. Sejarah Tuhan: Kisah 4000 Tahun Pencarian Tuhan dalam Agama-Agama Manusia. "Dia mengajarkan bahwa fana' (peniadaan diri) harus digantikan oleh baqa' (kekekalan diri), langkah kembali ke diri yang telah meningkat. Persatuan dengan Tuhan tidak boleh menghancurkan kemampuan alamiah kita, tetapi justru menyempurnakannya: seorang sufi yang telah menghilangkan egoisme yang bodoh dan menemukan kehadiran ilahi di dalam inti wujudnya sendiri akan mengalami kesadaran diri dan pengendalian diri yang lebih besar. Dia akan menjadi manusia yang lebih utuh. Oleh karena itu, tatkala mereka mengalami fana' dan baqa', kaum sufi telah mencapai keadaan yang oleh Yunani Kristen disebut "penuhanan". Al-Junaid memandang seluruh pencarian yang dilakukan oleh seorang sufi sebagai usaha kembali ke fitrah asal manusia pada saat penciptaan: dia kembali kepada kemanusiaan ideal yang telah ditetapkan oleh Tuhan. Dia juga kembali kepada Sumber eksistensinya. (Bandung: Mizan Media Utama, 2006), 303. 
(2) Di balik kecerian wajah si Cepot ada makna yang tersirat yang merefleksikan sesuatu yang sangat subtansial dalam menjalani kehidupan di muka bumi ini, yakni: kesabaran. Di dalam ajaran agama Islam, Kesabaran adalah proses untuk mencapai tingkatan keimanan yang lebih tinggi. Oleh karena itu, wujud si Cepot yang selalu tersenyum merefleksikan kesabaran yang sanggup untuk menghadapi segala probelmatika hidup dengan sabar-dengan senyuman. Senyuman si Cepot dapat diartikan sebagai keyakinan terhadap Tuhan sebagai Yang Maha Kuasa dan Yang Maha Adil, yang mustahil memberikan kesulitan yang melebihi kemampuan mahluknya. Asketisme para sufi sebetulnya merupakan bentuk kesabaran dalam menjalani kehidupannya. Kesabaran terhadap hal-hal yang duniawiyah dan kesabaran dalam pendakian spiritual. Selain itu, senyum lebar si Cepot dapat diartikan bahwa si Cepot memandang hidup ini hanyalah permainan saja-senda gurau semata ${ }^{9}$, sehingga ia hanya perlu bersabar dan tidak memusingkan segala sesuatunya karena telah ada yang mengatur, yakni Allah Swt. Adalah Nasruddin Hoja ${ }^{10}$ seorang sufi yang termasyhur karena kelakarnya. Di balik kelakarnya, Nasruddin Hoja dikenal sebagai seorang guru sufi dengan keutamaan ilmu yang sangat luas. Kelucuan wujud wajah si Cepot memperlihatkan konsep dualistik yang kompleks memperlihatkan anasir sufistiknya. Gigi si Cepot yang hanya satu itu, sama seperti Semar dapat diinterpretasikan sebagai kejujuran dalam berucap.

(3) Si Cepot memiliki warna tubuh yang sepenuhnya merah. Tetapi postur tubuh si Cepot terbilang cukup kecil. Warna merah dan tubuh yang kecil menyimbolkan keberanian seorang manusia walaupun bertubuh kecil. Hal ini merepresentasikan keberanian masyarakat akar rumput dalam menegakkan keadilan. Tubuh yang kecil dapat merepresentasikan masyarakat kecil, masyarakat akar rumput yang dalam konteks politis selalu termarjinalisasikan oleh sebuah kuasa. Warna merah

\footnotetext{
${ }^{9}$ Hal tersebut disebutkan di dalam beberapa ayat Al-Quran, antara lain: "Dan tiadalah kehidupan dunia ini, selain dari main-main dan senda gurau belaka. Dan sungguh kampung akhirat itu lebih baik bagi orang-orang yang bertakwa. Maka tidakkah kamu memahaminya?" (Surah Al-An'Am ayat 32). Dan, "Dan tiadalah kehidupan dunia ini melainkan senda gurau dan main-main. Dan sesungguhnya akhirat itulah yang sebenarnya kehidupan, kalau mereka mengetahui." (Surah Al-Ankabut ayat 64). Dan, "Sesungguhnya kehidupan dunia hanyalah permainan dan senda gurau. Dan jika kamu beriman serta bertakwa, Allah akan memberikan pahala kepadamu dan Dia tidak akan meminta harta-hartamu." (Surah Muhammad ayat 36).
}

10 Irwan Winardi. Cerita Jenaka Nasruddin Hoja. Nasruddin Hoja adalah seorang ulama Turki yang hidup di akhir abad ke-14 dan awal ke-15. Nasruddin Hoja lahir di desa Khortu, Sivri Hisar, Anatolia Tengah, Turki pada776 H/1372 M. Pertama dia mendapatkan pendidikan dari ayahnya yang menjadi seorang imam di kotanya. Sepeninggal ayahnya, Nasruddin diangkat sebagai imam menggantikan kedudukan ayahnya. Setelah itu dia pindah ke kota Ak Shehir, Propinsi Konya, untuk melanjutkan pendidikannya. Dia belajar kepada guru-guru terkenal pada masanya, di antaranya adalah Sayyid Mahmud Hairânî dan Sayyid Haji Ibrâhîm. Setelah menyelesaikan pendidikannya, dia diangkat sebagai hakim di kota Ak Shehir dan sekitarnya. Dia juga dikenal sebagai guru terpandang yang telah mendirikan beberapa perguruan dan madrasah di beberapa kota. Nasruddin adalah seorang guru sufi yang arif dan kaya dengan humor. Dalam memberikan pelajaran atau latihan-latihan keruhanian, tak jarang dia menggunakan humor yang membuka pikiran murid-muridnya. Nasruddin Hoja adalah ulama dari Mazhab Hanafî. Satu bidang yang sangat dia kuasai adalah ilmu fiqih. Karena keluasan ilmunya, dia mempunyai banyak murid yang berjumlah lebih dari tiga ratus orang. Dari sinilah dia mendapat gelar "Khawja" atau "Hoca" atau "Hoja” yang di masyarakat Indonesia sama dengan gelar "Kiai." Di wilayah Uighur, dia diberi tambahan gelar "Avanti" atau "Effendi." Di tempat lain dia diberi gelar "Maulana," "Mullah," dan "Syaikh." Melihat gelar-gelar yang melekat padanya, jelas dia merupakan tokoh yang dihormati. Bahkan dipercaya memiliki kekeramatan para wali." (Bandung: Pustaka Hidayah, 2006), 18-19. 
merupakan representasi dari keberanian dalam melawan kekuasaan yang tirani.

Di dalam Islam, keberanian harus didasarkan pada kejujuran. Sikap ini terlihat di dalam sifat ajaran agama Islam yang egalitarian, di mana semua orang pada dasarnya sama. Jika seorang muslim termarjinalkan, maka dirinya wajib melawan-walaupun dalam perlawanan yang kecil. Di dalam kebudayaan Sunda, warna merah merupakan warna Ratu, yakni penguasa dalam konteks politik. Warna merah merupakan sebuah simbol keberanian, di dalam konsep sufi menyimbolkan nafsu.

Konsep sufistik Al-Ghazali menjelaskan bahwa di dalam tubuh manusia ada empat warna yang melambangkan lima nafsu, yakni nafsu amarah yang dilambangkan dengan warna hitam. Nafsu syahwat yang dilambangkan dengan warna merah. Nafsu setani yang dilambangkan dengan warna kuning, nafsu sufiyah, dan mutmainah dilambangkan dengan warna putih. Kelima nafsu ini harus dikuasai seorang sufi agar mampu untuk membuka hijab-hijab yang tersembunyi sehingga cahaya Tuhan dapat memasuki dirinya ${ }^{11}$.

Si Cepot yang berkulit merah adalah simbol penguasaan terhadap nafsu syahwat yang bersifat keduniawian. Di dalam konsep sufi, nafsu keduniawian sangat dihindari. Mengingat Nabi Muhammad Saw. selalu menekankan pola hidup asketik. Masyarakat Sunda sudah sejak lama hidup dalam pola asketik yang "sejalan" dengan pola asketik di dalam konsep Sufi. Tangan si Cepot yang terlihat mengepal memperlihatkan sebuah tekad yang kuat dalam menjalani kehidupan. Juga memperlihatkan angka 0 (nol) yang dalam konsep sufi berarti ketiadaan seperti yang telah dijelaskan di atas.

(4) Si Cepot menggunakan busana Sunda, yakni pangsi yang berwarna hitam dengan tambahan elemen estestis yang berwarna putih dan bermotif kotak-kotak. Busana pangsi merupakan busana yang sangat sederhana tetapi memiliki simbol yang merepresentasikan keutamaan ilmu dalam pelbagai konteks. Misalnya, pangsi dalam konteks sufisme dapat dikatakan sebagai bentuk lain dari asketisme ${ }^{12}$. Hitam

\footnotetext{
11 Abdul Hadi W. M.Islam dalam Filsafat Mistik Jawa: Analisis Dewa Ruci dalam "Serat Cabolek". "Dalam kitabnya itu Imam al-Ghazali menyatakan bahwa dalam bentuk dan susunannya tubuh manusia itu mengandung empat campuran dan karenanya di dalamnya ada empat macam sifat, yaitu nafsu serigala (nafsu amarah), nafsu binatang (nafsu syahwat), nafsu setani (nafsu lawamah) dan nafsu malaikat (nafsu sufiyah) dan nafsu mutmainah (ketenangan) yang memancar dari sifat ketuhanan yang ada dalam diri manusia (Abdul Mudjieb 1986:39). Ketika manusia dikuasai oleh nafsu amarah yang dilambangkan dengan warna hitam, ia akan melakukan perbuatan serigala seperti senang akan permusuhan, penuh kebencian dan sangat agresif kepada manusia lain. Ketika seseorang dikuasai oleh syahwatnya, yang dilambangkan dengan warna merah, ia akan melakukan perbuatan binatang seperti lahap, rakus, brutal dan senang melampiskan nafsu berahinya. Selanjutnya begitu urusan ketuhanan meresap ke dalam hawa nafsunya, maka ia akan menganggap dirinya sebagai Tuhan. Ia mulai menyukai kekuasaan, keluhuran dan kebebasan, serta berkeinginan untuk menguasai dunia demi dirinya sendiri. Inilah nafsu setani yang dilambangkan dengan warna kuning. Nafsu sufiyah dan mutmainah dilambangkan dengan warna putih. Jika manusia dikuasai oleh sifat-sifat ketuhanan (rabbaniyah), kata Imam al-Ghazali, maka hidupnya akan dibimbing oleh ilmu, hikmah dan keyakinan dan mampu memahami hakikat segala sesuatu. Ia akan mengenal segala sesuatu dengan kekuatan ilmu dan mata hati. Akan memancar pula darinya sifat-sifat yang mulia seperti kesucian diri, suka menerima apa yang dianugerahkan kepadanya, tenang, zuhud, wara', taqwa, selalu riang hatinya, gemar menolong, punya rasa malu dan rasa bersalah."
}

12 Deni Mulyana Sasmita. Pangsi Khas Tatar Sunda. "Dilihat dari filosofinya, dia menyebutkan warna hitam pangsi itu warna alam, tanah. Selain itu, warna gelap itu bermakna sama dengan ajaran sufi yang menyebutkan 
adalah simbol bumi, simbol tanah, sedangkan tanah, di dalam ajaran Islam adalah simbol manusia ${ }^{13}$. Warna hitam memiliki konotasi yang negatif, betul, tapi tidak tepat. Warna hitam dalam konsep sufisme adalah keberawalan manusia dari ketidaktahuannya yang menyimbolkan kesabaran dalam pendakian spiritualitas kepada Tuhan Yang Maha Esa.

Syekh Abdul Qadir al-Jailani, misalnya, menafsirkan surah Al-Naba, "Dan kami jadikan malam sebagai pakaian dan kami jadikan siang untuk mencari penghidupan." (al-Naba 78: 10-11), sebagai rujukan bagi orang-orang yang akan, dan telah mencapai hakikat di dalam beragama-Islam. Karena baginya, seseorang yang telah dan sudah berada dalam kebenaran akan merasakan betapa gelapnya dunia. Mereka seakan-akan hidup di dalam penjara dengan pelbagai macam kesusahan dan kesukaran. Karena, siapapun yang hendak mencari kebenaran (Tuhan) akan melalui kegelapan tersebut sehingga, bagi Syekh Abdul Qadir al-Jailani warna hitam adalah warna yang menyimbolkan penderitaan spiritual seorang sufi sebelum mencapai tingkat kebenaran hingga akhirnya bisa mencicipi indah, kebenaran tersebut-persis seperti puisi Al-Hallaj dalam Diwan Qasidah.

Beberapa sufi sering menggunakan busana serba hitam sebagai sebuah bentuk asketisme. Artinya, merujuk pada penjelasan di atas, busana hitam merupakan sebuah simbol yang merepresentasikan persiapan diri dalam menghadapi penderitaan di jalan ruhani untuk menggapai kenikmatan transenden di dalam kebenaranNya. Terlihat jelas relasi antara warna hitam sebagai simbol bumi dengan warna hitam busana si Cepot dan warna hitam sebagai busana para sufi. Masing-masing merepresentasikan kesabaran, kesederhanaan, dan kesungguhan dalam melintasi jalan panjang ruhaniah demi mendapatkan kebenaraNya. Warna sarung yang digunakan oleh si Cepot secara merupakan elemen estetis yang digunakan sebagai pemanis saja.

\section{Eksistensial}

Secara eksistensial, wujud si Cepot memperlihatkan sinkretisme mutualistik antara kebudayaan Sunda dan ajaran agama Islam dalam konteks sufisme. Sinkretisme tersebut tersublimasikan dengan baik melalui kreativitas Alm. Asep Sunandar Sunarya yang membentuk paradoks yang justru membuat wujud si Cepotnya menjadi lebih otentik. Keotentikan tersebut secara implisit menghadirkan anasir sufistik vis a vis dengan kebudayaan Sunda melalui empat kelompok wujud, yakni: (1) Iket kepala, (2) Wajah termasuk giginya, (3) Tubuh, warna kulitnya, dan tanganya, (4) Busana. Keempat kelompok wujud terhubung dan membentuk anasir sufistiknya yang khas-yang kemungkinan besar hanya dapat ditemui pada si Cepot Alm. Asep Sunandar Sunarya.

\section{KESIMPULAN/RINGKASAN}

Sufisme menjadi bagian yang menjadi imanen di dalam perwujudan si Cepot Giri

dalam hitam itu ada pancaran cahaya tersendiri. "Selain itu, pakaian berwarna putih oleh orang zaman dahulu diasumsikan yang memakainya itu tergolong orang suci." Melalui:www.inilahkoran.com, 19/01/2014.

13 Al-Quran. "Dan (ingatlah), ketika Rabb-mu berfirman kepada para malaikat: "Sesungguhnya Aku akan menciptakan seorang manusia dari tanah liat kering (yang berasal) dari lumpur hitam yang diberi bentuk." (QS.Al-Hijr, 15:28) 
Harja 3. Kecenderungan tersebut muncul sebagai pengetahuan yang paradoks karena dihasilkan dari pertentangan-pertentangan antagonistik di dalamnya, sehingga kecenderungan tersebut memiliki formasiformasi parsialistik yang disebut juga sebagai anasir-anasir sufistik dari pelbagai konsep sufisme. Sufisme Imam Al-Ghazali dan Ibn Arabi terlihat sangat dominan sebagai anasir-anasir sufistik yang berkelidanan. Sufisme Imam Al-Ghazali muncul pada tataran formal syariati sebagai sebuah bentuk pengejawantahan pahampaham logis transenden, sedangkan sufisme Ibn Arabi muncul pada saat hakikat ketuhanan dimaknai dalam konteksnya yang paling substantil. Walaupun paham sufisme Ibn Arabi mendapat banyak pertentangan akan tetapi paham wujudiyahnya merupakan subtansi mistikisme di dalam ajaran agama Islam yang diakui oleh pelbagai konsep sufisme apapun, termasuk di dalam wujud si Cepot Giri Harja 3, yang disebut oleh Asep Sunarya Sunandar sebagai konsep ketauhidan!

\section{UCAPAN TERIMA KASIH}

Terima kasih untuk Tuhan Semesta Alam, Allah SWT. Yang telah memberikan kenikmatan yang tiada terbatas yakni ilmu pengetahuan. Shalawat dan salam semoga selalu tercurah kepada Kanjeng Rasullah Muhammad SAW. Kepada Universitas Telkom, rekan-rekan dosen, sahabat, dan keluarga besar Giri Harja 3. Untuk Almarhum bapak Asep Sunarya Sunandar, dan untuk redaktur Jurnal Kalatanda. Penulis menghaturkan banyak terima kasih atas semuanya kerjasamanya. 


\section{DAFTAR PUSTAKA}

[1] Al-Hadist.

[2] Al-Quran.

[3] Armstrong, Karen. 2006. Sejarah Tuhan Kisah Pencarian Tuhan Yang Dilakukan Oleh Orang-Orang Yahudi, Kristen, dan Islam Selama 4.000 Tahun. Mizan, Bandung.

[4] Hoed, Benny. 2011. Semiotika dan Dinamika Sosial Budaya. Depok: Komunitas Bambu.

[5] Jenks, Chris. 2013. Culture. Studi Kebudayaan. Pustaka Pelajar, Yogyakarta.

[6] Poespoprodjo, W. 2004. Hermeneutika. CV Pustaka Setia, Bandung.

[7] Ricoeur, Paul. 1981. Hermeneutics \& The Human Sciences. The Press Syndicate of The University of Cambridge, New York.

[8] Ricoeur, Paul. 2012. Teori Interpretasi. IRCiSoD, Yogyakarta.

[9] Sumardjo, Jakob. 2010. Estetika Paradoks (Edisi Revisi). Sunan Ambu Press, Bandung.

[10] Sumaryono, E. 1999. Hermeneutik, Sebuah Metode Filsafat (Edisi Revisi). Penerbit Kanisius, Yogyakarta.

[11] Wangi, Sena. 1982. Tetekon Padalangan Sunda. Balai Pustaka, Jakarta.

[12] Winardi, Irwan. 2006. Cerita Jenaka Nasruddin Hoja. Pustaka Hidayah, Bandung.

[13] Abdul Hadi W. M. Islam dalam Filsafat Mistik Jawa: Analisis Dewa Ruci dalam "Serat Cabolek".

[14] Deni Mulyana Sasmita. Pangsi Khas Tatar Sunda. Melalui: www.inilahkoran.com,

[15] Goenawan Mohamad. Punakawan. Melalui www.tempo.com/caping

[16] Suciati. Karakteristik Iket Sunda di Bandung dan Sumedang Periode Tahun 1968-2006.

(ITB J. Vis. Art \& Des., Vol. 2, No. 3, 2008), 239.

[17] Google.com/sicepot 


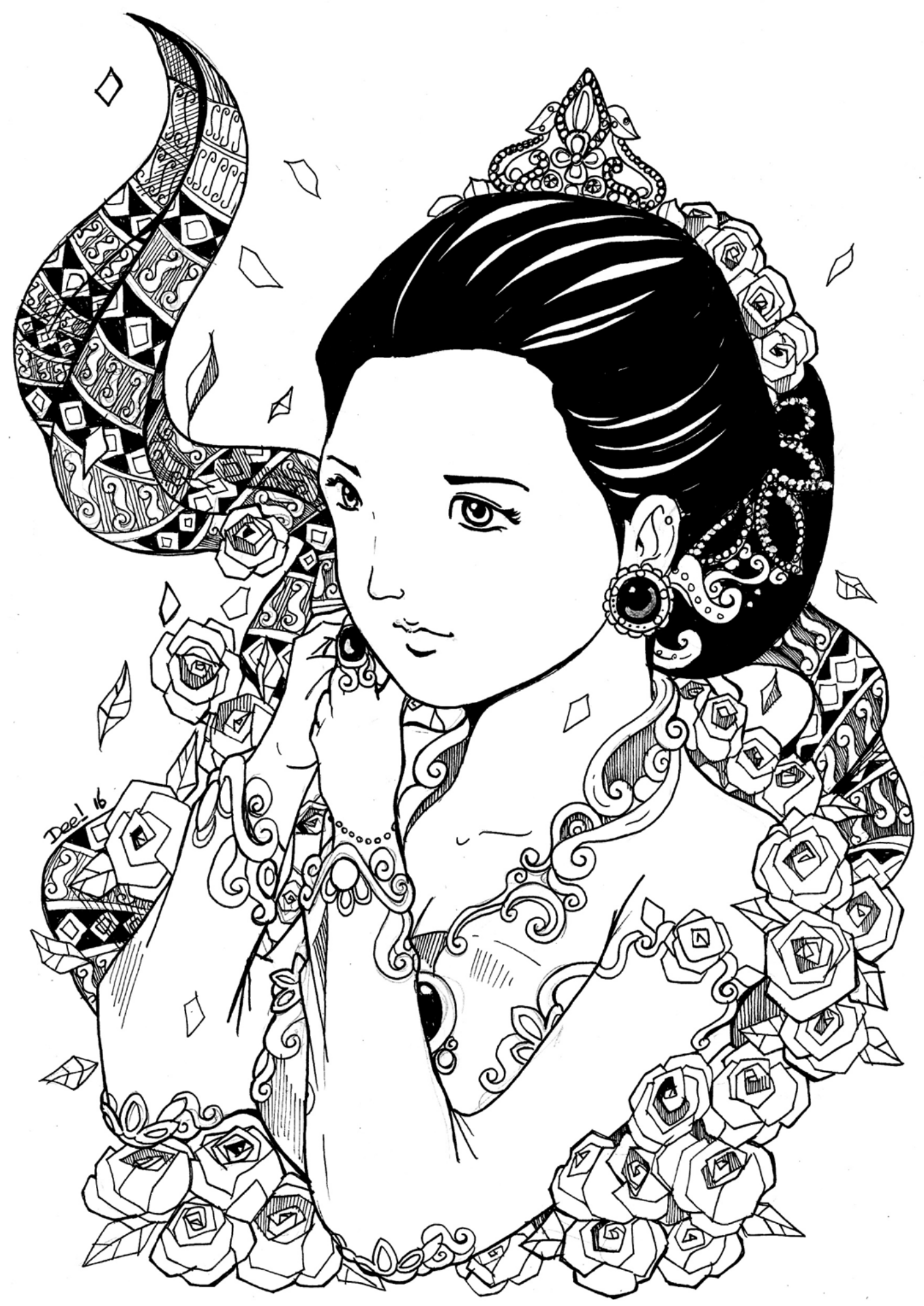

Java Beauty by Dimas Krisna Aditya, Mei 2016 